\title{
PENGARUH KEMUDAHAN DAN KEBERMANFAATAN SIMLITBANG DIKLAT TERHADAP PERILAKU WIDYAISWARA DALAM PENGGUNAANNYA
}

\author{
THE SIMPLICITY AND USABILITY OF SIMLITBANGDIKLAT \\ ON INFULENCING ATTITUDES TOWARS WIDYAISWARA AS USERS
}

Firman Nugraha

Balai Pendidikan dan Pelatihan Keagamaan Bandung Kementerian Agama RI e-mail: firmanugraha@kemenag.go.id

Naskah Diterima: 29 Januari 2020; Direvisi: 19 Mei 2020; Disetujui: 3 Agustus 2021

\begin{abstract}
The purpose of this study was to find out the effect of Simlitbangdiklat's simplicity and usefulness on its usage behavior by widyaiswara. The method used is descriptive with a positivistic approach. The data were obtained through questionnaires to widyaiswara in Bandung Religious Education and Training Center. The Data analysis uses statistics by a-means of SPSS version 21. The results of the t-test and probability test on the hypothesis showed that simplicity (X1) affected widyaiswara's behavior in using Simlitbangdiklat $(Y)$ with $R$ equal to 0,493 and the coefficient of determination was 0,243. At the same time, the usefulness of Simlitbangdiklat (X2) affected $Y$ with an $R$ of 0,397 and a determination coefficient of 0,158. Furthermore, X1X2 simultaneously influences $Y$ with $R$ of 0,586 and the determination coefficient of 0,343. So, this study concludes that Simlitbangdiklat simplicity and usefulness significantly influence the behavior of widyaiswara to use it.
\end{abstract}

Keywords: Effectiveness; Information Technology; Simlitbangdiklat; Widyaiswara

\begin{abstract}
Abstrak
Tujuan penelitian ini untuk menemukan pengaruh kemudahan dan kebermanfaatan Simlitbangdiklat terhadap perilaku widyaiswara. Metode yang digunakan adalah deskriptif dengan pendekatan positivistik. Data diperoleh melalui kuesioner terhadap widyaiswara di Balai Diklat Keagamaan Bandung. Analisis data menggunakan statistik berbantu SPSS versi 21. Hasil penelitian dan uji t serta uji probabilitas terhadap hipotesis menunjukkan bahwa kemudahan Simlitbangdiklat $\left(\mathrm{X}_{1}\right)$ berpengaruh terhadap perilaku widyaiswara dalam penggunaan Simlitbangdiklat (Y) dengan nilai $\mathrm{R}$ 0,493 dan nilai koefisien determinasi 0,243. Sedangkan kebermanfaatan Simlitbangdiklat $\left(\mathrm{X}_{2}\right)$ berpengaruh terhadap $\mathrm{Y}$ dengan $\mathrm{R}$ sebesar 0,397 dengan koefisien determinasi sebesar 0,158. Dan $\mathrm{X}_{1} \mathrm{X}_{2}$ secara bersamaan berpengaruh terhadap $\mathrm{Y}$ dengan $\mathrm{R}$ sebesar 0,586 serta koefisien determinasinya sebesar 0,343 . Jadi, hasil penelitian ini menyimpulkan bahwa kemudahan dan kebermanfaatan Simlitbangdiklat berpengaruh signifikan terhadap perilaku widyaiswara dalam penggunaannya.
\end{abstract}

Kata kunci: Efektivitas; Simlitbangdiklat; Teknologi Informasi; Widyaiswara 


\section{PENDAHULUAN}

Schwab (2016) mengidentifikasi bahwa abad 21 merupakan rangkaian dari revolusi industri, yang ia sebut sebagai generasi 4.0. Salah satu ciri penting abad ini adalah internet menjadi bagian integral dalam budaya masyarakat, dan tentu juga di lingkungan organisasi-organisasi publik sebagai kepanjangan tangan untuk memberikan layanan terbaik mereka kepada pengguna. Secara teknis, layanan organisasi dalam bentuk digital ini memanfaatkan perkembangan teknologi informasi (TI). Secara spesifik, TI dalam tatalaksana organisasi terhimpun dalam Sistem Informasi Manajemen (SIM) yang membantu layanan pegawai. Sistem informasi ini terkadang dimaknai secara sempit. Pemahaman ini mengerucut pada dua hal; pertama, sistem informasi dimaknai sebatas komputerisasi pekerjaan ketatausahaan; dan kedua, sistem informasi dimaknai sebagai "an all knowing computer which will provide answer and decision for complex problems when a manager simpley presses a few buttons" (Murdick, Ross, \& Clagett, 1996).

Badan Penelitian dan Pengembangan dan Pendidikan dan Pelatihan Kementerian Agama tidak terkecuali memanfaatkan TI untuk membangun Simlitbangdiklat. Layanan ini dapat diakses oleh pengguna di lingkungan kementerian agama di laman https://simlitbangdiklat.kemenag.go.id.

Aplikasi yang dibangun sejak tahun 2014 ini bermaksud untuk membantu para pegawai di lingkungan Balitbangdiklat baik tenaga fungsional maupun pelaksana dalam pelaksanaan tugas mereka. Secara khusus, karena ada dua besaran yang menjadi bidang garapan Balitbangdiklat yaitu pelatihan dengan tenaga fungsionalnya para widyaiswara dan penelitian dengan tenaga fungsionalnya para peneliti.

Simlitbangdiklat ini bertujuan untuk membantu para pegawai di lingkungan Pusdiklat dan Balai Diklat termasuk widyaiswara di dalamnya dalam kegiatan pelaksanaan diklat. Simlitbangdiklat menawarkan fasilitas bagi widyaiswara berupa akses informasi pribadi, sumber daya maupun aplikasi persuratan termasuk penghitungan Kelebihan Jam Mengajar (KJM). Idealnya hadirnya Simlitbangdiklat ini akan menghasilkan manfaat yang positif, mengurangi biaya organisasi, dan meningkatkan produktivitas pegawai (widyaiswara) (Tojib, Sugianto, \& Sendjaya, 2006); (Wulandari, Setyadi \& Aziz, 2019).

Balai Diklat Keagamaan Bandung bergabung dengan layanan simlitbangdiklat ini mulai tahun 2018 seiring dengan proyek pengalihan dan penggabungan dari sistem informasi serupa yang telah dirintis jauh-jauh hari oleh Balai Diklat Keagamaan Bandung. Layanan sistem informasi di Balai Diklat Keagamaan Bandung ini dinamakan Simdiklat karena khusus untuk kegiatan kediklatan. Kemudian seiring kebijakan penggabungan tersebut di atas agar menjadi skala nasional, Balai Diklat Keagamaan Bandung-pun menjadi bagian dari pengguna simlitbangdiklat.

Penggunaan simlitbangdiklat ini dalam perkembangannya oleh para widyaiswara dan pelaksana di Balai Diklat Keagamaan Bandung mengalami persoalan-persoalan teknis, seperti database yang berbeda, tampilan antar muka yang berbeda dengan simdiklat. Namun demikian, esensinya simlitbangdiklat ini terus digunakan sebagai sarana penunjang dalam kemudahan penyelesaian pekerjaan.

Berkenaan dengan persoalan tersebut di atas, diidentifikasi faktor teknis dan non teknis menjadi faktor penghambat dalam pemanfaatan Sistem Informasi (SI). Faktor teknis meliputi: (1) Teknologi dan infrastruktur. SI tentu memerlukan perangkat komputer, jaringan internet dan teknologi yang tepat. Persoalan yang kerap muncul adalah ketersediaan perangkat yang memadai sesuai dengan tuntutan SI tersebut. (2) Desain materi. Konten-konten data atau menu layanan yang tersedia dalam SI seyogianya berasal dari riset atau analisis kebutuhan yang berpusat kepada pengguna. (3) Pembiayaan. Persoalan ini memang menyentuh semua lapisan, termasuk pemerintahan. SI cukup sering terkendala pembiayaan pada pengadaan perangkat, jaringan maupun aplikasinya itu sendiri. Dalam hal ini jika SI diperlakukan dalam skala nasional dan pengadaannya dibebankan pada DIPA kementerian maka tentu akan membebani skema anggaran. (4) Sumber Daya Manusia yang mampu dan terampil dalam 
mendukung penerapan Sistem Informasi masih terbatas.

Sementara itu, faktor non-teknis meliputi: (1) Budaya. Pemanfaatan Sistem Informasi berbasis TI membutuhkan budaya akses dan kemandirian serta kebiasaan untuk memanfaatkan TI dalam pelaksanaan tugas. (2) Buta teknologi. Cukup dapat diterima bahwa meskipun sekarang masuk ke era 4.0 dalam penggunaan teknologi, namun para pegawai pada umumnya masih diisi oleh generasi X yaitu mereka yang masa kecilnya tumbuh bukan dalam bingkai budaya TI. Sehingga dapat dipahami jika masih ada yang belum menguasai teknologi komputer dan internet, atau yang terkait dengan TI lainnya.

Terkait dengan penelitian ini, sejauh yang diketahui ada beberapa penelitian terdahulu yang memiliki tema atau topik serupa. Goodhue dan Thompson dengan model Technology to Performance Chain (TPC) telah menguji komponen tugas, teknologi dan individual, serta interaksi dari tiga hal tersebut kepada dampak evaluasi pengguna (Goodhue \& Thompson, 1995). Penelitiannya ini menunjukkan adanya pengaruh pemanfaatan TI terhadap kinerja individual. Kedua, Penelitian Darwin menjadi bukti bahwa penggunaan komputer berpengaruh positif terhadap kinerja individu (Darwin, 1999). Penelitian-penelitian terbaru yang dilakukan Diana (2001). Dewi \& Dharmadiaksa (2017) juga mengkonfirmasi pengaruh pemanfaatan TI yang positif dan signifikan terhadap kinerja karyawan.

Agustiani, melihat pengaruh pemanfaatan sistem informasi akademik terhadap kinerja individu dan menunjukkan bahwa ada pengaruh yang positif (Agustiani, 2010). Sementara itu Subchan, Astuti, Kertahadi, mengukur efektivitas sistem informasi untuk mengetahui kesuksesan portal akademik menemukan bahwa ada pengaruh positif dan signifikan antara variabel kondisi portal akademik sebagai sistem informasi dengan manfaat individu (Subhan, Astuti, \& Kertahadi, 2012).

Sementara itu Honkis (2017) meneliti keberadaan Sistem Informasi Manajemen di Pendidikan Dasar dengan metode RnD menyimpulkan bahwa SIM yang dipandang memiliki nilai kemudahan dan kebermanfaatan dibangun dengan perencanaan yang matang. Sesuai dengan metode yang digunakan, penelitian ini masih bersifat model. Namun demikian, memberikan gambaran sistematis yang berkaitan dengan riset ini bahwa poin utama dibangunnya sebuah sistem informasi pada dasarnya membantu sebuah layanan administratif bagi pengguna. Hasil penelitian ini juga seperti dikonfirmasi Pardan dan Damayanthi (2017); Wijayanti, Sjahruddin, dan Razak (2017); Fatmayoni dan Yadnyana (2017) juga oleh Pratiwi dan Dharmadiaksa. (2018).

Penelitian di lingkungan Kementerian Agama dalam hal ini dilakukan Kibtiyah (2019) di Balai Diklat Keagamaan Denpasar. Penelitian dengan analisis Partial Least Square ini menunjukkan hasil bahwa (1) kualitas sistem tidak berpengaruh terhadap kegunaan aplikasi Simdiklat (2) kualitas informasi tidak berpengaruh terhadap kegunaan aplikasi Simdiklat (3) dukungan manajemen puncak berpengaruh positif terhadap kegunaan aplikasi Simdiklat (4) Kualitas sistem tidak berpengaruh positif terhadap kepuasan pengguna aplikasi Simdiklat (5) Kualitas informasi tidak berpengaruh terhadap kepuasan pengguna aplikasi Simdiklat (6) Dukungan manajemen puncak tidak berpengaruh terhadap kepuasan pengguna aplikasi Simdiklat (7) Kegunaan tidak berpengaruh terhadap kepuasan pengguna.

Berdasarkan literature review di atas, tampak bahwa penelitian tentang sistem informasi dan efektivitas pemanfaatannya banyak dilakukan dalam organisasi bisnis dan pendidikan. Sejauh penelusuran dalam informasi online masih belum ditemukan penelitian yang dilakukan di kementerian, secara khusus tentang pengaruh kemudahan dan kebermanfaatan Simlitbangdiklat di Kementerian Agama dan berlokasi di Balai Diklat Keagamaan Bandung.

Penelitian ini berupaya untuk menjawab rumusan masalah penelitian, yaitu (1) Apakah ada pengaruh kemudahan Simlitbangdiklat terhadap perilaku widyaiswara dalam penggunaannya?; (2) Apakah ada pengaruh kebermanfaatan Simlitbangdiklat terhadap perilaku widyaiswara dalam penggunaannya?; 
(3) Apakah ada pengaruh kemudahan dan kebermanfaatan Simlitbangdiklat secara bersamaan terhadap perilaku widyaiswara dalam penggunaannya?.

\section{KAJIAN TEORI}

Efektivitas adalah hasil-guna sesuai dengan tujuan. Efektif adalah berhasil, tepat, sesuai dengan tujuan yang telah ditentukan sebelumnya (Suharta, 2019). Efektivitas dalam konteks kinerja organisasi merupakan tolok ukur keberhasilan capaian tujuan organisasi (Mardiasmo, 2004). Efektif juga berarti tepat, manjur, mujarab, tepat guna dan berhasil manjur atau mujarab, dapat membawa hasil (al-Barry \& Dahlan, 2002). Jadi efektivitas adalah adanya kesesuaian antara orang yang melakukan tugas, dengan sasaran yang dituju. Kaitannya dalam keorganisasian, apabila suatu organisasi berhasil mencapai tujuannya, maka organisasi tersebut dikatakan efektif.

Efektif merupakan landasan untuk mencapai sukses. Makna ini memberi arti bahwa efektivitas berkenaan dengan derajat pencapaian tujuan, baik secara eksplisit maupun implisit, yaitu seberapa jauh tujuan tersebut tercapai. Efektivitas adalah suatu kondisi yang menunjukkan tingkat tercapainya suatu tujuan yang telah direncanakan sebelumnya. Terkait dengan penelitian ini, efektivitas yang dimaksud adalah kesesuaian antara tujuan hadirnya sistem informasi dengan pemanfaatan dan peningkatan kinerja penggunanya.

Perkembangan pemanfaatan teknologi sistem informasi telah tumbuh begitu pesat karena informasi menjadi sesuatu yang sangat penting, sehingga informasi menjadi salah satu kebutuhan pokok manusia. Informasi dikatakan penting karena didapatkan dari proses pembelajaran, pengalaman atau instruksi. Informasi dikatakan bermanfaat jika penggunaannya sesuai dengan kebutuhan. Beberapa manfaat informasi di antaranya adalah menambah pengetahuan atau mengurangi ketidakpastian pemakai informasi. Manfaat lainnya juga memberikan dasar kemungkinan menanggapi dan seleksi dalam pemenuhan kebutuhan informasi.

Mortense (1988) seperti dikutip Kurniawan (2008) menyatakan bahwa TI menjadi komponen yang tidak terpisahkan dari mekanisme kantor (Kurniawan, 2008). Hal ini tidak terlepas dari definisi TI seperti yang dikemukakan Sutabri (2014) bahwa TI adalah suatu teknologi yang digunakan untuk mengolah, memproses, mendapatkan, menyusun, menyimpan, memanipulasi data dalam berbagai cara untuk menghasilkan informasi yang berkualitas. Informasi yang berkualitas adalah relevan, akurat dan tepat waktu, baik untuk keperluan pribadi, bisnis, maupun pemerintahan. Dengan demikian menjadi informasi yang strategis untuk pengambilan keputusan.

Kemanfaatan teknologi berhubungan dengan perilaku menggunakan teknologi tersebut untuk menyelesaikan tugas. Model kemanfaatan teknologi informasi telah banyak diadopsi dari theory of attitudes and behavior yang dikembangkan oleh Triandis (1971) (Sunarta, 2005) dan theory of reasoned action oleh Fishbein dan Ajzen (1975) (Jogiyanto, 2005). Demikian pula halnya bahwa teknologi SI suatu perusahaan akan membantu penyediaan informasi dengan cepat sesuai dengan kebutuhan manajer dalam pengambilan keputusan (Ives, Olson, \& Baroudi, 1983). Selain sebagai alat bantu dalam pengolahan data, teknologi SI juga dapat digunakan untuk mengetahui lebih cepat jika timbul permasalahan dalam organisasi dan memfokuskan pada unsur tertentu guna mengambil tindakan yang tepat.

Pemanfaatan dan kepuasan pemakai menjadi tolok ukur keberhasilan SI (Torkzadeh \& Doll, 1999) (Amoroso \& Cheney, 2015). Para peneliti lain mendasarkan penelitiannya pada teori sikap dan perilaku aspek-aspek teknologi. Sistem yang berkualitas tinggi mempengaruhi sikap pemakai, berupa keyakinan dan afeksi terhadap sistem yang bersangkutan (Ives, Olson, \& Baroudi, 1983).

Terkait dengan penelitian ini tentang pemanfaatan sistem informasi, dapat dijelaskan dengan pandangan Davis (1989) dalam teori Technology Acceptance Model (TAM) bahwa persepsi pengguna akan menentukan sikapnya dalam kemanfaatan penggunaan TI (Fatmawati, 2015). Davis menggambarkan bahwa penerimaan penggunaan TI dipengaruhi oleh kemanfaatan (usefulness) dan kemudahan 
penggunaan (ease of use) (Davis, 1989). Kemanfaatan dan kemudahan penggunaan mempunyai pengaruh ke minat perilaku. Pemakai teknologi akan mempunyai minat menggunakan teknologi jika merasa sistem teknologi bermanfaat dan mudah digunakan. Pemakai SI akan lebih banyak memanfaatkan sistem jika SI tersebut mudah digunakan. Sebaliknya jika SI rumit dalam penggunaannya maka pemakai akan lebih sedikit dalam memanfaatkan SI tersebut.

Widyaiswara, seperti yang disebutkan dalam Peraturan Menteri Pemberdayaan Aparatur Negara Nomor 22 Tahun 2014 adalah Pegawai Negeri Sipil (PNS) yang diangkat sebagai pejabat fungsional oleh pejabat yang berwenang dengan tugas, tanggung jawab, wewenang untuk mendidik, mengajar, dan/atau melatih PNS pada lembaga pendidikan dan pelatihan (diklat) pemerintah. Terkait dengan tugas dan fungsinya untuk melaksanakan pendidikan, pengajaran dan pelatihan (dikjartih) maka perlu persiapan-persiapan seperti penyusunan bahan ajar, bahan tayang dan hal-hal administratif lainnya. Kehadiran TI tentu menjadi alat bantu yang akan menjadi faktor penting dalam meningkatkan kualitas kerja mereka.

Di lingkungan Kementerian Agama, khususnya Balitbang dan Diklat, kehadiran simlitbangdiklat menjadi hal yang niscaya seiring perkembangan TI termasuk bagi widyaiswara. Simlitbangdiklat dimaksudkan untuk membantu penggunanya termasuk widyaiswara dalam memperlancar proses maupun pengadminitrasian bukti-bukti fisik kinerja yang diperlukan dalam pelaporannya terutama untuk kepentingan pengajuan angka kredit. Simlitbangdiklat memiliki menu yang dibutuhkan bagi widyaiswara seperti persuratan untuk surat tugas dan pernyataan kegiatan. Penyediaan bahan diklat oleh widyaiswara bagi para peserta pelatihan dan kebutuhan para panitia. Menyediakan jadwal tatap muka dalam pelatihan berlangsung serta jumlah jam yang harus dilaksanakan. Hadirnya menu jadwal dan jam diklat ini pada gilirannya memberikan bantuan penting bagi widyaiswara untuk menghitung jumlah jam mengajar serta kelebihan jam mengajar dalam bulan tertentu.
Berangkat dari teori-teori di atas maka dapat digambarkan bahwa dalam penelitian ini kerangka pikirnya pada Gambar 1.

\begin{tabular}{|l|}
\hline SIM Diklat \\
\hline $\begin{array}{l}\text { 1. Kemudahan } \\
\text { 2. Kebermanfaata }\end{array}$
\end{tabular}$\Rightarrow$\begin{tabular}{|l|}
\hline Perilaku pengguna \\
\hline $\begin{array}{l}\text { Penggunaan SIM } \\
\text { Diklat }\end{array}$ \\
\hline
\end{tabular}

Gambar 1. Model konsep penelitian

Berdasarkan Davis (1989), dapat dijelaskan bahwa simlitbangdiklat dipandang mudah. Hal ini karena simlitbangdiklat dapat diakses dengan mudah dari luar kantor (komputer pribadi di rumah/warnet/smartphone). Simlitbangdiklat juga dapat diakses dengan mudah melalui fasilitas kantor. Selain itu, cara penggunaan simlitbangdiklat mudah untuk dipelajari. Susunan menu Simlitbangdiklat juga mudah untuk dipahami. Sedangkan dari sisi fasilitas yang ada, Simlitbangdiklat mudah untuk digunakan. Terakhir, kemudahan penggunaan Simlitbangdiklat memperlancar pekerjaan.

Sementara itu merujuk kepada rumusan Goodhue and Thompson (1995), dimensi kebermanfaatan Simlitbangdiklat dapat dilihat dari dua hal. Pertama, penggunaannya yang meningkatkan efektivitas dalam mengerjakan tugas-tugas kantor. Kedua, pelayanan departemen sistem informasi/bagian TI merupakan bantuan yang penting serta sangat berharga bagi pelaksanaan kinerja tugas. Ketiga, produktivitas widyaiswara akan meningkat dengan menggunakan Simlitbangdiklat dalam melaksanakan tugastugasnya setiap hari.

Sedangkan dimensi perilaku pengguna (widyaiswara) dalam penggunaan Simlitbangdiklat dapat dilihat dari hal-hal yang diuraikan Goodhue and Thompson (1995). Pertama, Intensitas dari penggunaan Simlitbangdiklat dalam satu hari (berhubungan dengan pekerjaan). Kedua, frekuensi dari penggunaan Simlitbangdiklat dalam periode tertentu seperti jam, hari, minggu dan bulan. Ketiga, banyaknya menu Simlitbangdiklat yang digunakan dalam pekerjaan

Dari pemikiran di atas, maka hipotesis penelitian ini adalah: 
1. Kemudahan penggunaan Simlitbangdiklat berpengaruh terhadap penggunaannya oleh widyaiswara.

2. Kebermanfaatan Simlitbangdiklat berpengaruh terhadap penggunaannya oleh widyaiswara.

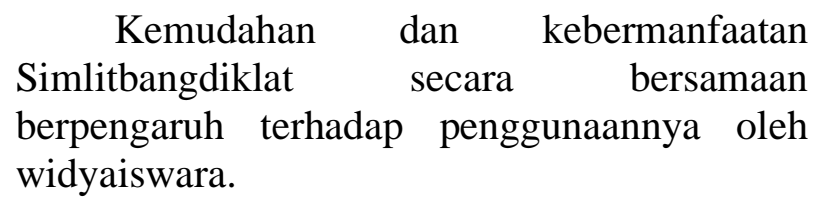

\section{METODOLOGI}

Penelitian ini menggunakan paradigma positivisme yang dari segi prosesnya memungkinkan pada akhirnya menggunakan pengolahan data secara statistik (Sugiono, 2009). Menurut Sugiono aliran positivisme, dalam memandang gejala, lebih bersifat tunggal, statis, dan konkret. Metode yang digunakan dalam penelitian ini adalah kuantitatif dengan analisis deskriptif verifikatif. Sugiono (2009) menyatakan dalam penelitian kuantitatif, peneliti menggunakan instrumen untuk mengumpulkan data atau mengukur status variabel yang diteliti. Jadi dalam penelitian ini melakukan analisis data untuk menguji hipotesis.

Sejalan dengan hal tersebut, teknik pengumpulan data dilakukan dengan kuesioner pada populasi penelitian. Sumber data penelitian ini adalah para widyaiswara di Balai Diklat Keagamaan Bandung yang menggunakan Simlitbangdiklat. Secara keseluruhan jumlah widyaiswara di Balai Diklat Keagamaan Bandung adalah 40 orang (dikurangi satu sebagai peneliti). Dengan demikian maka seluruh widyaiswara akan dijadikan responden. Dalam hal ini, ada pengecualian, yaitu peneliti sendiri tidak menjadi bagian dari responden yang diambil data. Dari segi jumlah responden, penelitian ini termasuk ke dalam penelitian populasi (Arikunto, 2002). Populasi adalah keseluruhan objek yang akan diteliti. Menurut Riduan dan Kuncoro (2008), populasi generalisasi yang terdiri dari subyek yang menjadi kuantitas dan karakteristik tertentu yang ditetapkan peneliti untuk dipelajari dan kemudian ditarik kesimpulannya (Kuncoro \& Riduwan, 2008).

Proses pengumpulan data, tidak semulus yang diharapkan. Ada dua kendala yang dihadapi. Pertama, kehadiran widyaiswara yang menjadi responden menjadikan jumlah jawaban terkumpul hanya 32 orang dari keseluruhan populasi. Kedua, telah diusahakan melalui kuesioner online. Namun demikian, tidak seluruhnya berkesempatan mengisi instrumen online tersebut. Jadi, sampai tanggal 23 Desember 2019 total responden yang berkenan mengisi instrumen berjumlah 32 dari 39 orang responden yang ditargetkan.

Teknik pengumpulan data sesuai dengan pendekatannya yaitu kuantitatif dan kebutuhannya untuk menemukan pengaruh kemudahan dan kebermanfaatan Sistem Informasi, maka data primer dilakukan melalui angket (Bungin, 2010). Selain itu, wawancara dan pengamatan juga dilakukan kepada beberapa partisipan pengguna SIM dimaksud. Pengumpulan data dilakukan secara manual melalui instrumen hasil print out dan instrumen online yang disusun melalui layanan google form dibagikan melalui aplikasi WhatsApp pada grup widyaiswara Balai Diklat Keagamaan Bandung.

Analisis dalam penelitian ini menggunakan analisis verifikatif. Analisis verifikatif adalah suatu kerangka kerja yang melihat hubungan antara dua variabel atau lebih, yaitu melihat objek dengan mengungkap kejelasan hubungan sebab akibat antar variabel. Langkah ini dilakukan untuk menjawab pertanyaan penelitian.

Penelitian ini karena dilakukan dengan angket, maka sebelumnya perlu dilakukan pengujian instrumen. Namun demikian karena dengan skala responden yang terbatas jumlah populasinya maka pengujian validitas dan reliabilitas dilakukan secara simultan dalam pengujian hipotesis penelitian dengan memanfaatkan aplikasi SPSS ver. 21. Pengujian hipotesis dilakukan setelah menentukan rumusan hipotesis nol $\left(\mathrm{H}_{\mathrm{o}}\right)$ dan hipotesis alternatif $\left(\mathrm{H}_{\mathrm{a}}\right)$ juga menentukan tingkat signifikansi penelitian sebesar 5\% (atau 0.05). Teknik yang digunakan adalah regresi linier. Sedangkan penafsiran data menggunakan koefisien determinasi melalui penghitungan koefisien korelasi product moment.

Rumusan hipotesis yang akan diuji adalah: 
$\mathrm{H}_{\mathrm{a}}: \mathrm{X}$ berpengaruh terhadap $\mathrm{Y}$

$\mathrm{H}_{\mathrm{o}}: \mathrm{X}$ tidak berpengaruh terhadap $\mathrm{Y}$

Rumusan hipotesis dalam bentuk statistik adalah:

$$
\begin{aligned}
& \mathrm{H}_{\mathrm{a}}: \mathrm{P} \neq 0 \\
& \mathrm{H}_{\mathrm{o}}: \mathrm{P}=0
\end{aligned}
$$

Model regresi linier menurut Muhidin dan Abdurahman adalah (Abdurahman \& A, 2007):

$$
\mathrm{Y}=\mathrm{a}+\mathrm{bX}
$$

Y sebagai variabel dependen, sementara $\mathrm{X}$ variabel independen. Dimana $a$ adalah penduga bagi intersap $(\alpha)$, dan $b$ adalah penduga bagi koefisien regresi $(\beta)$. Sedangkan $\alpha$ dan $\beta$ adalah parameter yang nilainya diketahui menggunakan statistik sampel. Rumus yang digunakan untuk mencari $a$ dan $b$ adalah:

Tabel 1. Interpretasi terhadap koefisien korelasi

Interval koefisien korelasi
$0,00-0,199$
$0,20-0,399$
$0,40-0,599$
$0,60-0,799$
$0,80-1,00$
er: diadaptasi dari Sugiyono (2008)
Selain mencari koefisien korelasi deter
diketahui koefisien determinasi digunakan
sien den detam
rahui seberapa besar (dalariabe
ruh variabel X terhadap varian digunakan adalah:
$\rho^{2} .100 \%$
Koefisien determinasi
oefisien korelasi product moment

Uji signifikansi ditujukan oleh hasil perhitungan SPSS versi 21 dalam tabel correlation dengan melihat nilai Sig. (2 tailed) (Kuncoro \& Riduwan, 2008). berikut:

Kaidah keputusannya adalah sebagai

1. Jika nilai probabilitas 0.05 lebih kecil atau sama dengan nilai probabilitas sig atau $(0.05 \leq$ Sig. $)$, maka $\mathrm{H}_{\mathrm{o}}$ diterima dan $\mathrm{H}_{\mathrm{a}}$ ditolak, artinya tidak signifikan. perlu diketahui koefisien determinasi. Koefisien determinasi digunakan untuk mengetahui seberapa besar (dalam \%) Rumus yang digunakan adalah:

$\mathrm{Kd}=\rho^{2} .100 \%$

$\mathrm{Kd}=$ Koefisien determinas

$\mathrm{P}=$ Koefisien korelasi product moment

$$
\begin{aligned}
& \mathrm{a}=\frac{\sum Y-b \sum X}{N}=\overline{\mathrm{y}}-b X \\
& \mathrm{~b}=\frac{N\left(\sum X Y\right)-\sum X \sum Y}{N \sum X^{2}-\left(\sum X\right)^{2}}
\end{aligned}
$$

Keterangan

$\mathrm{X}_{\mathrm{i}}=$ rata - rata skor variabel $\mathrm{X}$

$\mathrm{Y}_{\mathrm{i}}=$ rata - rata skor variabel $\mathrm{Y}$

Nilai a dan $b$ dalam penelitian ini dihitung dengan SPSS versi 21.

Koefisien korelasi menggunakan teknik korelasi product moment. Rumus yang digunakan adalah:

$$
\rho=\frac{N\left(\sum X i Y i\right)-\sum X i \sum Y i}{\left.\sqrt{\left\{N \sum X_{i}^{2}\right.}-\left(\sum X\right)^{2}\right\}\left\{N \sum Y_{i}^{2}-(\Sigma Y i)^{2}\right\}}
$$

hasil ini kemudian dibandingkan dengan $\rho$ tabel, dengan tahap kesalahan tertentu. Penafsiran lain juga dilakukan menggunakan tabel ketentuan sebagai berikut: pengaruh variabel $\mathrm{X}$ terhadap variabel $\mathrm{Y}$.

el

Tingkat Hubungan

Sangat rendah

Rendah

Sedang

Kuat

Sangat Kuat

2. Jika nilai probabilitas 0,05 lebih besar dari nilai probabilitas Sig. atau $(0,05>\mathrm{Sig})$, maka $\mathrm{H}_{\mathrm{o}}$ ditolak dan $\mathrm{H}_{\mathrm{a}}$ diterima, artinya signifikan.

Untuk pengujian hipotesis $\mathrm{H}_{\mathrm{o}}$ ditolak atau diterima, juga melihat pengaruh secara signifikan terhadap variabel bebas (X) dan variabel terikat $(\mathrm{Y})$ juga menggunakan rumus uji t, yaitu:

$$
\mathrm{t}=\frac{\rho \sqrt{N-2}}{\sqrt{1-\rho^{2}}}
$$

Hipotesis yang akan diuji adalah:

$\mathrm{H}_{\mathrm{a}}=\mathrm{X}$ berpengaruh signifikan terhadap $\mathrm{Y}$

$\mathrm{H}_{\mathrm{o}}=\mathrm{X}$ tidak berpengaruh signifikan terhadap Y

Hipotesis dalam bentuk statistik adalah:

$\mathrm{H}_{\mathrm{a}}: \mathrm{P} \neq 0$
$\mathrm{H}_{0}: \mathrm{P}=0$

Nilai t hitung menggunakan SPSS versi 21 untuk mengetahui nilainya, sedangkan $t$ tabel 
dilihat pada tabel t dengan memperhatikan tingkat signifikansi yang diperlukan dan derajat kebebasan. adalah:

Kaidah keputusan yang digunakan

1. Jika nilai $\mathrm{t}_{\text {hitung }}>\mathrm{t}$ tabel, maka $\mathrm{H}_{\mathrm{o}}$ ditolak dan $\mathrm{H}_{\mathrm{a}}$ diterima, artinya $\mathrm{X}$ berpengaruh secara signifikan terhadap $\mathrm{Y}$.

2. Jika nilai $\mathrm{t}_{\text {hitung }} \leq \mathrm{t}$ tabel, maka $\mathrm{H}_{\mathrm{o}}$ diterima dan $\mathrm{H}_{\mathrm{a}}$ ditolak, artinya $\mathrm{X}$ tidak berpengaruh secara signifikan terhadap Y.
HASIL DAN PEMBAHASAN

\section{Analisis Deskriptif Kemudahan Penggunaan Simlitbangdiklat}

Berikut ini disajikan hasil pengolahan data untuk variabel Kemudahan Penggunaan Simlitbangdiklat $\left(\mathrm{X}_{1}\right)$. Hasil berikut merupakan hasil mandiri tanpa melihat hubungan dengan variabel lainnya.

Tabel 2. Hasil pengolahan data untuk aspek kemudahan penggunaan Simlitbangdiklat

\begin{tabular}{lll}
\hline Item Pertanyaan & Mean & Kriteria \\
\hline $\begin{array}{l}\text { Simlitbangdiklat dapat diakses dengan mudah dari luar kantor } \\
\text { (komputer pribadi di rumah/warnet/smartphone) }\end{array}$ & 3,484 & Rendah \\
\hline $\begin{array}{l}\text { Simlitbangdiklat dapat diakses dengan mudah melalui fasilitas } \\
\text { kantor. }\end{array}$ & 4,032 & Tinggi \\
\hline $\begin{array}{l}\text { Cara penggunaan Simlitbangdiklat mudah untuk dipelajari } \\
\text { Susunan menu Simlitbangdiklat mudah untuk dipahami }\end{array}$ & 3,935 & Tinggi \\
\hline $\begin{array}{l}\text { Fasilitas yang ada pada Simlitbangdiklat mudah untuk digunakan } \\
\text { Kemudahan penggunaan Simlitbangdiklat memperlancar } \\
\text { pekerjaan }\end{array}$ & 3,935 & Tinggi \\
\hline Kemudahan Penggunaan Simlitbangdiklat & $\mathbf{3 , 7 8 6}$ & Singgi \\
\hline
\end{tabular}

Sumber: Pengolahan data primer

Berdasarkan Tabel 2 di atas, diketahui bahwa kemudahan penggunaan Simlitbangdiklat dipandang sedang. Hal yang menarik dalam data ini adalah dimensi penggunaan Simlitbangdiklat yang dapat diakses secara mudah di luar kantor masuk ke dalam kategori rendah. Hal tersebut berbanding terbalik dengan dimensi akses Simlitbangdiklat di kantor. Dengan demikian, Simlitbangdiklat dipandang mudah dan digunakan hanya dalam kepentingan kantor dengan cara diakses melalui layanan jaringan internet di kantor. Hal tersebut seperti dikonfirmasi pada dimensi-dimensi lainnya yang menunjukkan kategori tinggi.

\section{Analisis Deskriptif Kebermaanfaatan Simlitbangdiklat}

Pemanfaatan Simlitbangdiklat berkaitan dengan pekerjaan widyaiswara dalam hal dikjartih. Menu yang tersedia dalam Simlitbangdiklat memang memenuhi kebutuhan widyaiswara seperti tata persuratan maupun penghitungan jam mengajar dan penilaian bagi peserta. Hasil pengolahan pada aspek pemanfaatan Simlitbangdiklat seperti dalam Tabel 3.

Tabel 3. Hasil pengolahan data untuk aspek kebermanfaatan Simlitbangdiklat

\begin{tabular}{lll}
\hline Item Pertanyaan & Mean & Kriteria \\
\hline Intensitas penggunaan Simlitbangdiklat dalam satu hari & 2,531 & Rendah \\
\hline Frekuensi Penggunaan Simlitbangdiklat & 3,281 & Tinggi \\
\hline Banyaknya menu Simlitbangdiklat yang dimanfaatkan & 2,469 & Rendah \\
\hline Pemanfaatan Simlitbangdiklat & $\mathbf{2 , 7 6 9}$ & Sedang \\
\hline
\end{tabular}

Sumber: Pengolahan data primer

Berdasarkan tabel 3 diketahui bahwa pemanfaatan Simlitbangdiklat oleh widyaiswara termasuk sedang. Hal ini berarti widyaiswara mengakses Simlitbangdiklat 
hanya bila berkenaan dengan adanya tugas yang memerlukan penggunaannya saja. Seperti terlihat dalam intensitas penggunaannya dalam satuan hari tergolong rendah. Karena memang, widyaiswara tidak selalu harus melaksanakan aktivitas online hanya dengan Simlitbangdiklat. Ada juga aplikasi lain yang digunakan oleh widyaiswara terutama untuk aspek pelaporan kinerja yaitu aplikasi e-office.

\section{Sementara itu, frekuensi pemanfaatan yang tinggi menunjukkan bahwa} Simlitbangdiklat memang memiliki manfaat nyata bagi widyaiswara dalam menunjang kegiatannya dalam dikjartih termasuk kebutuhan pengadministrasiannya lebih lanjut. Namun demikian, menu yang terkonfirmasi digunakan tampaknya baru sedikit. Seperti terlihat dari tabel 3 tersebut yang menunjukkan kategori rendah. Hal ini karena widyaiswara dalam pemanfaatan Simlitbangdiklat baru terbatas keperluan tata persuratan dinas.
Terutama hubungannya dengan kepentingan pelaporan dan usulan angka kredit dari kegiatan dikjartih.

\section{Analisis Deskriptif Perilaku Penggunaan Simlitbangdiklat oleh Widyaiswara}

Terkait dengan perilaku penggunaan Simlitbangdiklat oleh widyaiswara termasuk sedang. Meskipun widyaiswara berpendapat bahwa penggunaan Simlitbangdiklat mampu meningkatkan efektivitas pekerjaan. Hal tersebut seperti terlihat pada tabel 4 dengan kategori tinggi. Kondisi ini, dikonfirmasi dengan layanan sistem IT sebagai bantuan yang berharga dalam pelaksanaan tugas. Dengan demikian widyaiswara menyadari dan menerima konteks perubahan tata kelola kantor menuju layanan yang modern berbasis IT. Hal ini sejalan dengan kondisi umum di mana IT telah menjadi bagian penting dalam layanan kantor.

Tabel 4. Hasil pengolahan data perilaku penggunaan Simlitbangdiklat oleh widyasiwara

\begin{tabular}{lll}
\hline Item Pertanyaan & Mean & Kriteria \\
\hline $\begin{array}{l}\text { Penggunaan Simlitbangdiklat meningkatkan efektivitas saya dalam } \\
\text { mengerjakan tugas-tugas kantor }\end{array}$ & & Tinggi \\
\hline $\begin{array}{l}\text { Pelayanan departemen sistem informasi/bagian TI merupakan } \\
\text { bantuan yang penting serta sangat berharga bagi pelaksanaan } \\
\text { kinerja tugas saya. }\end{array}$ & & Tinggi \\
\hline $\begin{array}{l}\text { Produktivitas saya akan meningkat dengan menggunakan } \\
\text { Simlitbangdiklat untuk melaksanakan tugas-tugas saya setiap hari. }\end{array}$ & & \\
\hline \begin{tabular}{l} 
Penggunaan Simlitbangdiklat oleh Widyaiswara \\
\hline
\end{tabular} & $\mathbf{3 , 8 9 6}$ & Sedang \\
\hline
\end{tabular}

Sumber: Pengolahan data primer

Meskipun demikian, widyaiswara juga berpendapat bahwa produktivitas kerja dengan Simlitbangdiklat dalam posisi yang rendah. Hal ini disinyalir terkait dengan tugas pokok dan fungsi widyaiswara yang ada dalam area dikjartih. Sebagaimana dipahami bersama aktivitas dikjartih berada dalam ruang belajar dengan teknologi informasi berbeda yang digunakannya. Aplikasi yang lebih sering dipakai tentu berkenaan dengan multimedia untuk presentasi. Termasuk di dalamnya adalah dalam penyusunan bahan persiapan dikjartih. Pada kasus ini, Simlitbangdiklat tidak berdampak langsung dengan produktivitas widyaiswara dalam aktivitas dikjartih.

\section{Analisis Verifikatif Pengaruh Kemudahan Penggunaan Simlitbangdiklat terhadap Perilaku Widyaiswara dalam Penggunaan Simlitbangdiklat $\left(\mathbf{X}_{1} \mathbf{Y}\right)$}

Analisis verifikatif merupakan uji hipotesis untuk melihat hubungan dan pengaruh yang terjadi dari variabel penelitian. Berdasarkan hasil penelitian pada widyaiswara di Balai Diklat Keagamaan Bandung, analisa hubungan menggunakan regresi linier dan korelasi antar variabel. Variabel yang diuji adalah kemudahan penggunaan Simlitbangdiklat $\left(\mathrm{X}_{1}\right)$ dengan perilaku widyaiswara dalam penggunaan Simlitbangdiklat (Y). Berdasarkan penghitungan menggunakan SPSS (ver. 21) 
diperoleh korelasi dan regresi linier sebagai berikut.

Tabel 5. Model summary

\begin{tabular}{lllll}
\hline Model & R & R Square & Adjusted R Square & Std. Error of the Estimate \\
\hline 1 &, $493^{\mathrm{a}}$ &, 243 &, 218 &, 18059 \\
\hline
\end{tabular}

a. Predictors: (Constant), Indeks Kemudahan Penggunaan Simlitbangdiklat

Dari tabel 5 Model Summary di atas Simlitbangdiklat. Berdasarkan nilai R yang diperoleh nilai $\mathrm{R}$ 0,493 dan harga koefisien determinasi ( $\mathrm{R}_{\text {square }}$ ) 0,243. Hal ini memberi arti bahwa perilaku widyaiswara dalam penggunaan Simlitbangdiklat dipengaruhi sebesar 24,3 persen oleh kemudahan kategori sedang dalam rentang Guilfold, artinya kemudahan Simlitbangdiklat pengaruhnya cukup terhadap perilaku penggunaan Simlitbangdiklat itu sendiri.

Tabel 6. ANOVA ${ }^{\mathrm{a}}$

\begin{tabular}{lllllll}
\hline Model & & Sum of Squares & df & Mean Square & F & Sig. \\
\hline \multirow{3}{*}{1} & Regression &, 314 & 1 &, 314 & 9,638 &, $004^{\mathrm{b}}$ \\
\cline { 2 - 8 } & Residual &, 978 & 30 &, 033 & & \\
\cline { 2 - 8 } & Total & 1,293 & 31 & & & \\
\hline
\end{tabular}

a. Dependent Variable: Indeks Perilaku Pengguna Simlitbangdiklat

b. Predictors: (Constant), Indeks Kemudahan Penggunaan Simlitbangdiklat

Tabel 7. Coefficients ${ }^{\mathrm{a}}$

\begin{tabular}{|c|c|c|c|c|c|}
\hline \multirow[t]{2}{*}{ Model } & & $\begin{array}{l}\text { Unstandardized } \\
\text { Coefficients }\end{array}$ & $\begin{array}{l}\text { Standardized } \\
\text { Coefficients }\end{array}$ & \multirow[t]{2}{*}{$\mathrm{t}$} & \multirow[t]{2}{*}{ Sig. } \\
\hline & $\mathrm{B}$ & Std. Error & Beta & & \\
\hline (Constant) & ,459 & , 108 & & 4,241 & ,000 \\
\hline $\begin{array}{l}1 \text { Indeks Kemudahan } \\
\text { Simlitbangdiklat }\end{array}$ & Penggunaan ,427 & , 138 & ,493 & 3,105 & ,004 \\
\hline
\end{tabular}

a. Dependent Variable: Indeks Perilaku Pengguna Simlitbangdiklat

Hasil uji coefficient seperti terlihat pada tabel 7 di atas nilai konstanta a adalah 0,459 dan $b$ adalah 0,493 dengan harga $t$ hitung sebesar 3,105 tingkat signifikansinya 0,004. Berdasarkan penghitungan ini diperoleh rumus persamaan regresi linier: $\mathrm{Y}=0,459+0,493$ $\mathrm{X}_{1}$.

Persamaan ini memperlihatkan bahwa pengaruh kemudahan Simlitbangdiklat terhadap perilaku widyaiswara dalam pemanfaatannya dapat diprediksi. Semakin mudah Simlitbangdiklat digunakan akan semakin tinggi perilaku widyaiswara dalam penggunaan Simlitbangdiklat.

Untuk menguji apakah hipotesis diterima atau ditolak dan seberapa besar signifikansinya maka digunakan uji t dan teknik probabilitas.

\section{Uji t}

Rumusan hipotesis yang diuji adalah:
$\mathrm{H}_{\mathrm{a}}=$ Kemudahan
penggunaan Simlitbangdiklat signifikan terhadap perilaku widyaiswara dalam penggunaannya.
$\mathrm{H}_{\mathrm{o}}=$ Kemudahan penggunaan Simlitbangdiklat tidak berpengaruh signifikan terhadap perilaku widyaiswara dalam penggunaannya
$\mathrm{t}$ hitung berdasarkan tabel koefisien di atas sebesar 3,105. Sementara itu $\mathrm{t}$ tabel untuk tingkat signifikan $\alpha=0,05$ dan derajat kebebasan $32-1=31$ sebesar 1,696. Berdasarkan penghitungan tersebut diketahui bahwa $t_{\text {hitung }}>\mathrm{t}$ tabel atau 3,105 > 1,696 maka $\mathrm{H}_{\mathrm{o}}$ di tolak dan $\mathrm{H}_{\mathrm{a}}$ diterima, artinya signifikan. Jadi, kemudahan Simlitbangdiklat dalam penggunaannya berpengaruh terhadap perilaku widyaiswara dalam penggunaan Simlitbangdiklat. 


\section{Teknik probabilitas}

Diketahui menurut tabel koefisien variabel kemudahan penggunaan Simlitbangdiklat dan perilaku widyaiswara dalam penggunaan Simlitbangdiklat nilai sig. sebesar 0,004. Nilai sig tersebut jika dibandingkan dengan nilai probabilitas sebesar 0,05 maka nilai probabilitas > dari nilai sig. $(0,05>0,004)$, artinya $\mathrm{H}_{\mathrm{o}}$ di tolak dan $\mathrm{H}_{\mathrm{a}}$ diterima, bermakna signifikan. Sehingga, kemudahan Simlitbangdiklat dalam penggunaannya berpengaruh signifikan terhadap perilaku widyaiswara dalam penggunaan Simlitbangdiklat. Hasil korelasi variabel $\mathrm{X}_{1}$ dengan $\mathrm{Y}$ dengan teknik korelasi product moment adalah 0,493. Berdasarkan tabel 1 hal ini berarti terdapat hubungan yang sedang antara variabel kemudahan penggunaan Simlitbangdiklat dengan perilaku widyaiswara dalam penggunaan Simlitbangdiklat

\section{Analisis Verifikatif Pengaruh Pemanfaatan Simlitbangdiklat terhadap Perilaku Widyaiswara dalam Simlitbangdiklat $\left(\mathbf{X}_{2} \mathbf{Y}\right)$ \\ Penggunaan}

Berikut ini hasil pengujian terhadap variabel kebermanfaatan Simlitbangdiklat $\left(\mathrm{X}_{2}\right)$ dengan perilaku widyaiswara dalam penggunaan Simlitbangdiklat (Y). Berdasarkan penghitungan menggunakan SPSS (ver. 21) diperoleh korelasi dan regresi linier sebagai berikut.

Tabel 8. Model Summary

\begin{tabular}{lrrrr}
\hline Model R & \multicolumn{2}{c}{ R Square } & Adjusted R Square & Std. Error of the Estimate \\
\hline 1 &, $397^{\mathrm{a}}$ &, 158 &, 130 &, 19051
\end{tabular}

a. Predictors: (Constant), Indeks Pemanfaatan Simlitbangdiklat

Dari tabel 8. Model Summary di atas diperoleh harga $\mathrm{R} \quad 0.397$ dan koefisien determinasi ( $\left.R_{\text {square }}\right)$ 0.158. Hal ini menyatakan bahwa perilaku widyaiswara dalam penggunaan Simlitbangdiklat dipengaruhi sebesar 15.8 persen oleh kemudahan Simlitbangdiklat. Artinya, sebesar 84.2 persen dipengaruhi oleh faktor-faktor lainnya. Berdasarkan harga $\mathrm{R}$ yang kategori sedang dalam rentang Guilfold, artinya kebermanfaatan Simlitbangdiklat pengaruhnya rendah terhadap perilaku penggunaan Simlitbangdiklat itu sendiri.

Tabel 9. ANOVA ${ }^{\mathrm{a}}$

\begin{tabular}{llrrrrr}
\hline Model & Sum of Squares & df & & Mean Square & F & Sig. \\
\hline \multirow{3}{*}{1} & Regression &, 204 & 1 &, 204 & 5,619 &, $024^{\mathrm{b}}$ \\
\cline { 2 - 7 } & Residual & 1,089 & 30 &, 036 & & \\
\cline { 2 - 7 } & Total & 1,293 & 31 & & & \\
\hline
\end{tabular}

a. Dependent Variable: Indeks Perilaku Pengguna Simlitbangdiklat

b. Predictors: (Constant), Indeks Pemanfaatan Simlitbangdiklat

Tabel 10. Coefficients ${ }^{\mathrm{a}}$

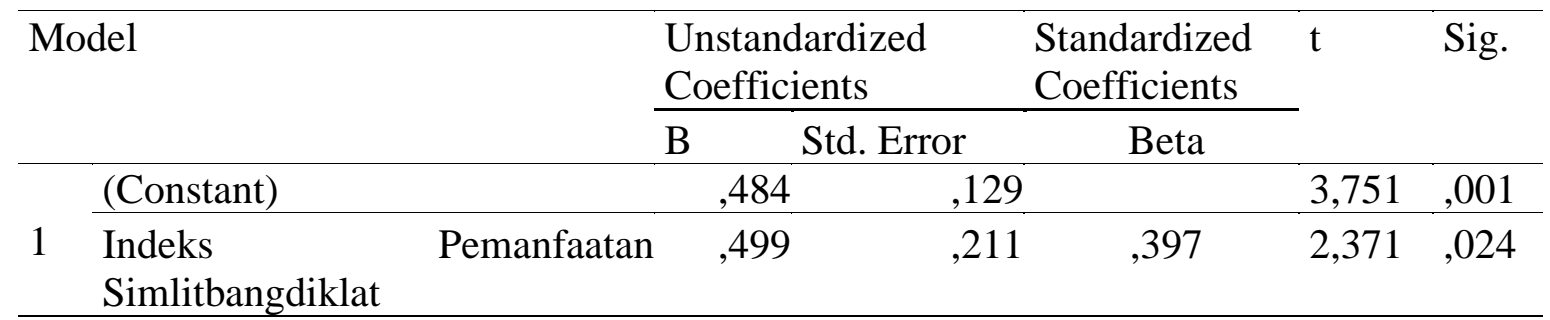

a. Dependent Variable: Indeks Perilaku Pengguna Simlitbangdiklat

Hasil uji coefficient dalam tabel 10 menunjukkan bahwa nilai konstanta a 0,484 dan $b$ 0,397 dengan harga $t$ hitung 2,371 dan signifikansinya adalah 0,024. Dari penghitungan ini diperoleh persamaan regresi linier: $\mathrm{Y}=0,484+0,397 \mathrm{X}_{2}$. Persamaan ini 
menunjukkan bahwa semakin bermanfaat Simlitbangdiklat maka akan semakin tinggi perilaku widyaiswara dalam penggunaan Simlitbangdiklat.

Untuk menguji apakah hipotesis diterima atau ditolak dan seberapa besar signifikansinya maka digunakan uji t dan teknik probabilitas.

\section{Uji $t$}

Rumusan hipotesis yang diuji, yaitu:

$\mathrm{H}_{\mathrm{a}}=$ Kebermanfaatan Simlitbangdiklat berpengaruh signifikan terhadap perilaku widyaiswara dalam penggunaannya.

$\mathrm{H}_{\mathrm{o}}=$ Kebermanfaatan Simlitbangdiklat tidak berpengaruh signifikan terhadap perilaku widyaiswara dalam penggunaannya

$\mathrm{t}$ hitung diketahui sebesar 2,371 sementara itu $\mathrm{t}$ tabel untuk tingkat signifikansi $\alpha=0,05$ dengan derajat kebebasan 32-1 = 31 sebesar 1,696. Berdasarkan penghitungan tersebut diketahui bahwa $\mathrm{t}_{\text {hitung }}>\mathrm{t}$ tabel atau 2,371 >1,696 maka $\mathrm{H}_{\mathrm{o}}$ di tolak dan $\mathrm{H}_{\mathrm{a}}$ diterima, artinya signifikan. Jadi, kebermanfaatan Simlitbangdiklat berpengaruh terhadap perilaku widyaiswara dalam penggunaan Simlitbangdiklat.

\section{Teknik probabilitas}

Tabel 11. Model summary

\begin{tabular}{lllll}
\hline Model & R & R Square & Adjusted R Square & Std. Error of the Estimate \\
\hline 1 &, $586^{\mathrm{a}}$ &, 343 &, 298 &, 17115 \\
\hline
\end{tabular}

a. Predictors: (Constant), Indeks Pemanfaatan Simlitbangdiklat, Indeks Kemudahan Penggunaan Simlitbangdiklat

Berdasarkan tabel 11. Model Summary di atas nilai $\mathrm{R}$ 0,586 dan harga koefisien determinasi ( $\mathrm{R}_{\text {square }}$ ) 0,343. Hal ini memberi pengertian bahwa Perilaku Widyaiswara dalam Penggunaan Simlitbangdiklat dipengaruhi sebesar 34,3 persen oleh kemudahan dan kebermanfaatan Simlitbangdiklat. Artinya,
Berdasarkan tabel koefisien variabel kebermanfaatan Simlitbangdiklat dan perilaku widyaiswara dalam penggunaan Simlitbangdiklat nilai sig. sebesar 0,024. Nilai sig tersebut jika dibandingkan dengan nilai probabilitas sebesar 0,05 artinya nilai probabilitas $>$ dari nilai sig. $(0,05>0,024)$, dengan demikian $\mathrm{H}_{\mathrm{o}}$ ditolak dan $\mathrm{H}_{\mathrm{a}}$ diterima, artinya signifikan. Sehingga, kebermanfaatan Simlitbangdiklat berpengaruh signifikan terhadap perilaku widyaiswara dalam penggunaan Simlitbangdiklat. Hasil korelasi variabel $\mathrm{X}_{2}$ dengan $\mathrm{Y}$ dengan teknik korelasi product moment adalah 0,397. Berdasarkan tabel 1 hal ini berarti terdapat hubungan yang rendah antara variabel kebermanfaatan Simlitbangdiklat dengan perilaku widyaiswara dalam penggunaan Simlitbangdiklat.

\section{Analisis Verifikatif Pengaruh Kemudahan dan Pemanfaatan Simlitbangdiklat secara bersamaan terhadap Perilaku Penggunaannya oleh Widyaiswara $\left(\mathrm{X}_{1} \mathrm{X}_{2} \mathrm{Y}\right)$}

Berikut ini adalah analisis variabel Kemudahan dan Pemanfaatan Simlitbangdiklat secara bersamaan terhadap Perilaku Penggunaannya oleh Widyaiswara $\left(\mathrm{X}_{1} \mathrm{X}_{2} \mathrm{Y}\right)$. Berdasarkan penghitungan menggunakan SPSS (ver. 21) diperoleh korelasi dan regresi linier sebagai berikut.

Tabel 12. ANOVA ${ }^{a}$

\begin{tabular}{lllllll}
\hline Model & & Sum of Squares & df & Mean Square & F & Sig. \\
\hline \multirow{3}{*}{1} & Regression &, 443 & 2 &, 222 & 7,568 &, $002^{\mathrm{b}}$ \\
\cline { 2 - 7 } & Residual &, 849 & 29 &, 029 & & \\
\cline { 2 - 7 } & Total & 1,293 & 31 & & & \\
\hline
\end{tabular}

a. Dependent Variable: Indeks Perilaku Pengguna Simlitbangdiklat 
b. Predictors: (Constant), Indeks Pemanfaatan Simlitbangdiklat, Indeks Kemudahan Penggunaan Simlitbangdiklat

Tabel 13. Coefficients ${ }^{\mathrm{a}}$

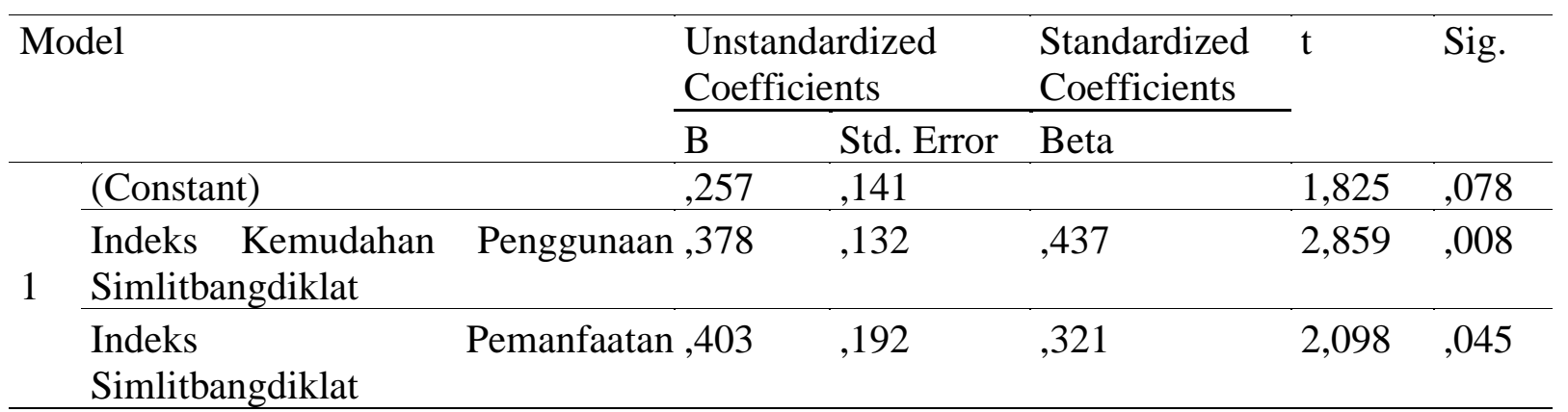

a. Dependent Variable: Indeks Perilaku Pengguna Simlitbangdiklat

Hasil uji coefficient seperti terlihat dalam tabel 13 menunjukkan bahwa nilai konstanta a adalah 0,257 dan $b$ adalah 0,321 dengan harga $\mathrm{t}$ hitung sebesar 2,098. dan tingkat signifikansinya adalah 0,045. Dari penghitungan ini diperoleh persamaan regresi linier: $\mathrm{Y}=0,257+0,437+0,321 \mathrm{X}_{1} \mathrm{X}_{2}$. Persamaan ini menunjukkan pengertian bahwa semakin mudah dan bermanfaat Simlitbangdiklat maka akan semakin tinggi perilaku widyaiswara dalam penggunaan Simlitbangdiklat.

Untuk menguji apakah hipotesis diterima atau ditolak dan seberapa besar signifikansinya maka digunakan uji t dan teknik probabilitas.

\section{Uji t}

Rumusan hipotesis yang diuji, yaitu:

$\mathrm{H}_{\mathrm{a}}=$ Kemudahan dan Kebermanfaatan Simlitbangdiklat secara bersamaan berpengaruh signifikan terhadap perilaku widyaiswara dalam penggunaannya.

$\mathrm{H}_{\mathrm{o}}=$ Kemudahan dan Kebermanfaatan Simlitbangdiklat secara bersamaan tidak berpengaruh signifikan terhadap perilaku widyaiswara dalam penggunaannya

$\mathrm{t}$ hitung diketahui sebesar 2,371. Sementara itu $\mathrm{t}$ tabel untuk tingkat signifikansi $\alpha=0,05$ dengan derajat kebebasan 32-1 = 31 sebesar 1,696. Berdasarkan penghitungan tersebut diketahui bahwa $t_{\text {hitung }}>\mathrm{t}$ tabel atau 2,098 >1,696, maka $\mathrm{H}_{\mathrm{o}}$ di tolak dan $\mathrm{H}_{\mathrm{a}}$ diterima, artinya signifikan. Jadi, kemudahan dan kebermanfaatan Simlitbangdiklat secara bersamaan berpengaruh terhadap perilaku widyaiswara dalam penggunaan Simlitbangdiklat.

\section{Teknik probabilitas}

Menurut tabel koefisien variabel kemudahan dan kebermanfaatan Simlitbangdiklat dan perilaku widyaiswara dalam penggunaan Simlitbangdiklat nilai sig. sebesar 0,045. Dengan demikian nilai probabilitas > dari nilai sig. $(0,05>0,045)$, maka $\mathrm{H}_{\mathrm{o}}$ di tolak dan $\mathrm{H}_{\mathrm{a}}$ diterima, artinya signifikan. Sehingga, Kemudahan dan Kebermanfaatan Simlitbangdiklat secara bersamaan berpengaruh signifikan terhadap perilaku widyaiswara dalam penggunaan Simlitbangdiklat. Hasil korelasi variabel $\mathrm{X}_{1} \mathrm{X}_{2}$ dengan $\mathrm{Y}$ dengan teknik korelasi product moment adalah 0,586. Berdasarkan tabel 11 hal ini berarti terdapat hubungan yang Sedang antara variabel kemudahan dan kebermanfaatan Simlitbangdiklat secara bersamaan terhadap perilaku widyaiswara dalam penggunaan Simlitbangdiklat.

Berdasarkan analisis di atas, maka hasil dan temuan dalam penelitian ini cenderung mendukung terhadap hasil-hasil penelitian sebelumnya yang menyatakan ada pengaruh positif TI terhadap perilaku penggunaannya (Darwin, 1999; Goodhue and Thompson, 1995; Davis, 1989). Namun demikian, hasil penelitian ini juga cenderung menolak hasil penelitian Kibtiyah (2019) dengan subjek serupa yaitu Simdiklat di Balai Diklat Keagamaan Denpasar dengan hasil yang cenderung negatif. Dengan demikian, penelitian ini menyatakan bahwa pertama, sistem informasi pada dasarnya akan diterima 
positif oleh pengguna dengan syarat memiliki nilai kemudahan dalam mengaksesnya sekalipun oleh orang yang minimal pengetahuan dan keterampilannya tentang TI. Kedua, sistem informasi juga akan diterima positif oleh penggunanya jika memiliki nilai manfaat yang tinggi. Artinya aplikasi ini memang menjadi satu-satunya sarana yang dapat meningkatkan performa pengguna dalam menyelesaikan pekerjaannya.

\section{PENUTUP}

Berdasarkan hasil dan pembahasan pada penelitian ini, maka dapat ditarik kesimpulan bahwa Simlitbangdiklat efektif digunakan oleh widyaiswara dengan argumen kemudahan dan kebermanfaatan Simlitbangdiklat berpengaruh secara signifikan terhadap perilaku penggunaannya oleh widyaiswara. Hal ini dilihat dari:

a. Analisis deskriptif menunjukkan bahwa kemudahan Simlitbangdiklat berada pada nilai rata-rata 3,786 dengan kriteria sedang. Dari keseluruhan indikator yang diterapkan seperti kemudahan diakses di kantor, kemudahan cara penggunaan untuk dipelajari, kemudahan memahami susunan menu kemudahan menggunakan fasilitas di Simlitbangdiklat serta kaitannya dengan kelancaran pekerjaan menunjukkan hasil yang tinggi. Hasil yang rendah hanya ditunjukkan pada aspek kemudahan digunakan di luar kantor, seperti di rumah, maupun smartphone. Meskipun demikian, berarti sebagai alat, Simlitbangdiklat memang mudah untuk digunakan oleh widyaiswara.

b. Analisis deskriptif untuk kebermanfaatan Simlitbangdiklat menunjukkan nilai ratarata 2,769 dengan kriteria sedang. Dari keseluruhan indikator, frekuensi pemanfaatan menunjukkan hasil yang tinggi. Namun aspek intensitas dan banyaknya menu yang dimanfaatkan menunjukkan hasil yang rendah. Artinya pemanfaatan Simlitbangdiklat oleh widyaiswara tinggi namun dengan intensitas dalam satuan hari yang masih rendah dengan menu yang terbatas.

c. Analisis deskriptif pada perilaku penggunaan Simlitbangdiklat oleh widyaiswara menunjukkan nilai rata-rata
3,896 dengan kriteria sedang. Dari keseluruhan indikator yang diterapkan seperti penggunaan Simlitbangdiklat meningkatkan efektivitas kerja, dan pelayanan departemen TI menunjukkan hasil yang tinggi. Kecuali, penggunaan Simlitbangdiklat terkait dengan produktivitas kerja menunjukkan hasil yang rendah. Hal ini berarti Simlitbangdiklat telah efektif digunakan oleh widyaiswara meskipun kaitannya dengan produktivitas kerja masih rendah.

d. Hasil uji hipotesis dengan uji t dan uji probabilitas menunjukkan bahwa kemudahan penggunaan Simlitbangdiklat berpengaruh signifikan terhadap perilaku penggunaannya oleh widyaiswara. Nilai $R$ sebesar 0,493 dan koefisien determinasi ( $\left.\mathrm{R}_{\text {square }}\right)$ sebesar 0,243. Hal ini menunjukkan pengertian bahwa perilaku widyaiswara dalam penggunaan Simlitbangdiklat dipengaruhi sebesar 24,3 persen oleh kemudahannya. Nilai R ini ada dalam rentang sedang, artinya kemudahan Simlitbangdiklat pengaruhnya cukup terhadap perilaku penggunaan Simlitbangdiklat itu sendiri.

e. Hasil uji hipotesis dengan uji $t$ dan uji probabilitas menunjukkan bahwa kebermanfaatan Simlitbangdiklat berpengaruh signifikan terhadap perilaku penggunaannya oleh widyaiswara. $\mathrm{R}$ sebesar 0,397 dan koefisien determinasi ( $\left.\mathrm{R}_{\text {square }}\right)$ sebesar 0,158. Hal ini menunjukkan pengertian bahwa perilaku widyaiswara dalam penggunaan Simlitbangdiklat dipengaruhi sebesar 15,8 persen oleh kebermanfaatan Simlitbangdiklat. Artinya, sebesar 84,2 persen dipengaruhi oleh faktor-faktor lainnya. Nilai $\mathrm{R}$ ini ada dalam rentang sedang, artinya kebermanfaatan Simlitbangdiklat pengaruhnya cukup terhadap perilaku penggunaan Simlitbangdiklat itu sendiri.

f. Hasil uji hipotesis dengan uji t dan uji probabilitas menunjukkan bahwa kemudahan dan kebermanfatan Simlitbangdiklat secara bersamaan berpengaruh signifikan terhadap perilaku penggunaannya oleh widyaiswara. $\mathrm{R}$ sebesar 0,586 dan koefisien determinasi 
( $\left.\mathrm{R}_{\text {square }}\right) \quad$ sebesar 0,343. Hal ini menunjukkan pengertian bahwa perilaku widyaiswara dalam penggunaan Simlitbangdiklat dipengaruhi sebesar 34,3 persen oleh kemudahan dan kebermanfaatan Simlitbangdiklat. Artinya, sebesar 65,7 persen dipengaruhi oleh faktor-faktor lainnya.

Berdasarkan hasil dan kesimpulan di atas, maka penelitian ini menghasilkan saransaran sebagai berikut:

a. Diketahui bahwa nilai rendah pada variabel kemudahan penggunaan Simlitbangdiklat $\left(\mathrm{X}_{1}\right)$ ada pada aspek penggunaan di luar kantor. Sesungguhnya penyedia layanan sudah menyediakan IP public untuk Simlitbangdiklat agar bisa diakses di luar kantor. Kondisi yang terjadi, informasi tersebut disampaikan melalui whatapps group, maka sering tertimpa oleh informasi baru lainnya. Oleh karena itu Balai Diklat Keagamaan Bandung perlu memperluas akses informasi yang statis seperti dalam bentuk lembar informasi tercetak.

b. Pada variabel kebermanfaatan Simlitbangdiklat, indikator yang rendah adalah aspek intensitas dan banyaknya menu yang diakses oleh widyaiswara. Hal ini terkait dengan masih tersebarnya kegiatan widyaiswara pada beberapa aplikasi, sehingga dalam satu hari widyaiswara pada dasarnya memang menggunakan IT dalam kegiatannya namun dengan intensitas yang rendah untuk masing-masing aplikasi. Dengan demikian, Balai Diklat Keagamaan Bandung, Pusdiklat Tenaga Teknis Pendidikan dan Keagamaan, Badan Litbang dan Diklat untuk merumuskan dan menyusun aplikasi tunggal bagi pegawai termasuk widyaiswara.

Pada variabel perilaku widyaiswara dalam penggunaan Simlitbangdiklat (Y) pada umumnya indikator hasil menunjukkan nilai tinggi, kecuali aspek produktivitas kinerja. Seperti halnya dengan variabel kebermanfaatan $\left(\mathrm{X}_{2}\right)$, hal ini terjadi karena tugas dan fungsi dan kegiatan widyaiswara tidak seluruhnya direkam dan dilaporkan melalui aplikasi Simlitbangdiklat. Ada aplikasi lain yang juga digunakan yaitu di antaranya aplikasi e-office.
Dengan demikian, ke depan seluruh aspek kegiatan widyaiswara ada dalam satu aplikasi.

\section{DAFTAR PUSTAKA}

Abdurahman, M., \& A, M. S. (2007). Analisis Korelasi, Regresi, dan Jalur dalam Penelitian. Bandung: Pustaka Setia.

Agustiani, N. H. (2010). Pengaruh Pemanfaatan Sistem Informasi Akademik Terpadu (Sikadu) Terhadap Kinerja Individual Dengan Kemudahan Penggunaan Sebagai Variabel Moderating (Studi Empiris pada Fakultas Teknik Universitas Negeri Semarang). Semarang: Undip.

al-Barry, P. P., \& Dahlan, M. (2002). Kamus Ilmiah Populer. Surabaya: Arkola.

Amoroso, D. R., \& Cheney, P. H. (2015). Testing a Causal Model of End-User Application Effectiveness. 63-89. doi:https://doi.org/10.1080/07421222.1 991.11517911

Arikunto, S. (2002). Metodologi Penelitian. Jakarta: Penerbit PT. Rineka Cipta.

Bungin, B. (2010). Metode Penelitian Kualitatif. Jakarta: Rajawali Pers.

Darwin, R. (1999). Komputerisasi Pasar Swalayan: Implikasi Terhadap Kinerja Karyawan. Semarang: MAKSI UNDIP.

Davis, F. D. (1989, September). Perceived Usefulness, Perceived Ease of Use and User Acceptance of Computer Technology. MIS Quertely.

Fatmawati, E. (2015, Mei). Technology Acceptance Model (Tam) Untuk Menganalisis Penerimaan Terhadap Sistem Informasi Perpustakaan. Jurnal Iqra, 09(01).

Goodhue, D., \& Thompson, R. (1995). TaskTechnology Fit and Individual Performance. MIS Quarterly, 19(2), 213-236.

Ives, B., Olson, M. H., \& Baroudi, J. (1983, October). The Measurement of User Information Satisfaction. Communications of the ACM, 26(10), 785-793. 
Jogiyanto, H. (2005). Analisis \& Disain Sistem Informasi: Pendekatan Terstruktur, Teori dan Praktek Aplikasi Bisnis. Yogyakarta: Andi.

Kuncoro, E. A., \& Riduwan. (2008). Cara menggunakan dan memaknai Analisis Jalur. Bandung : Alfabeta.

Kurniawan, R. (2008). Analisis Pengaruh Teknologi Informasi Pada Kinerja Organisasi Study Empiris PT. Bank Rakyat Indonesia (PERSERO) Tbk Unit Kantor Cabang Tegal, Kantor Wilayah Semarang. Semarang: MAKSI UNDIP.

Mardiasmo. (2004). Otonomi dan Manajemen Keuangan Daerah. Yogyakarta : Andi.

Murdick, R. G., Ross, J. E., \& Clagett, J. R. (1996). Sistem Informasi untuk Manajemen Modern (Vol. III). (Djamil, Trans.) Jakarta: Penerbit Erlangga.

Sugiono. (2009). Metode Penelitian Pendidikan Pendekatan Kuantitatif, Kualitatif, $R \& D$. . Bandung: Penerbit Alfabeta.

Suharta, S. R. (2019). Efektivitas Sistem Informasi Kelurahan (Sik) Dalam
Meningkatkan Pelayanan Publik (Studi Pada Kelurahan Sisir Kota Batu). JISIP: Jurnal Ilmu Sosial dan Ilmu Politik, 8(2), 64-69.

Sunarta, I. N. (2005). Analisis Faktor-Faktor Yang Mempengaruhi Pemanfaatan Teknologi Informasi dan Pengaruh Pemanfaatan Teknologi Informasi Terhadap Kinerja Individual. Semarang: MAKSI UNDIP.

Tojib, D. R., Sugianto, L.-F., \& Sendjaya, S. (2006). A conceptual model for B2E portal user satisfaction. International Conference on Business and Information (BAI) (pp. 1-17). Academy of Taiwan Information Systems Research.

Torkzadeh, G., \& Doll, W. J. (1999). The Development of a Tool for Measuring The Perceived Impact of Information Technology On Work: Omega. The International Journal of Management Science, 27(3), 327 - 339. 